Article

\title{
Effect of Composting Parameters on the Power Performance of Solid Microbial Fuel Cells
}

\section{Chin-Tsan Wang ${ }^{1, *}$, Yao-Cheng Lee ${ }^{2}$ and Fan-Ying Liao ${ }^{1}$}

1 Department of Mechanical and Electro-Mechanical Engineering, National I-Lan University, I-Lan 26047, Taiwan; E-Mail: r9922012@ms.niu.edu.tw

2 Institute of Materials Science and Engineering, National Taipei University of Technology, Taipei 10608, Taiwan; E-Mail: t103789003@ntut.edu.tw

* Author to whom correspondence should be addressed; E-Mail: ctwang@niu.edu.tw; Tel.:+886-3-935-7400 (ext. 7459); Fax: +886-3-931-1326.

Academic Editor: Arnulf Jäger-Waldau

Received: 31 May 2015 / Accepted: 9 September 2015 / Published: 15 September 2015

\begin{abstract}
Nowadays, solid organic waste is of major environmental concern and is reaching critical levels worldwide. Currently, a form of natural decomposition, known as composting technology, is widely used to deal with organic waste. This method is applied to enhance the performance of solid microbial fuel cells (SMFCs) in this study. Operational composting parameters (carbon/nitrogen ratio, moisture content and $\mathrm{pH}$ value) are investigated to explore the optimal power performance of solid microbial fuel cells (SMFCs). Results indicate that the carbon/nitrogen ratio and the moisture content displayed the most significant impact on SMFCs. When the carbon/nitrogen ratio is 31.4 and moisture content is $60 \%$, along with a $\mathrm{pH}$ value of 6-8, a better SMFC power performance would be obtained. These findings would provide positive information regarding the application of compost in SMFCs.
\end{abstract}

Keywords: organic waste; moisture content; carbon/nitrogen ratio ( $\mathrm{C} / \mathrm{N}$ ratio); solid microbial fuel cell (SMFC); power performance

\section{Introduction}

Solid organic waste is a major source of environmental pollution. The large accumulation of agricultural waste, animal husbandry excrement and urban garbage has become a serious environmental issue [1], with various methods being used to help solve it [2,3]. Currently, the composting method is 
widely utilized in the treatment of solid organic waste [4]. This method uses natural microorganisms to decompose and convert the organic waste into mature compost, which would then be applied to microbial fuel cells (MFCs) to enhance power performance[5,6]. MFCs use bacterial reactions to generate electricity and handle the organic matter in all kinds of waste, such as domestic sewage, agricultural waste, sewage sludge in sewage treatment plants, livestock waste water, food waste water and lingo cellulosic biomass [7]. Combined bioremediation [8] and microbial treatment in SMFCs can actually reduce the concentration of pollutants. In this study, composting-related operational technology would be applied to the SMFCs due to its similar biochemical reaction process.

In applying composting technology to SMFCs, the relevant operating parameters in compost are found to have an important impact on their electrical performance and are therefore worth further exploration. Important influencing factors in composting include $\mathrm{C} / \mathrm{N}$ ratio, moisture content and $\mathrm{pH}$ value, of which the $\mathrm{C} / \mathrm{N}$ ratio heavily affects the microorganism growth in compost. If the $\mathrm{C} / \mathrm{N}$ ratio is lower than 20, microorganism activity is limited. On the other hand, when the $\mathrm{C} / \mathrm{N}$ ratio is higher than 40, the compost is deemed harmful to the environment. General compost needs an optimal $\mathrm{C} / \mathrm{N}$ ratio of about 25 to 35 to enable the quickest composting procedure [9]. The moisture content in the compost affects the conduction of the substrate and microbial metabolism [10]. Excessive moisture (above 80\%) will hinder oxygen supply and carbon dioxide efflux, resulting in the accumulation of harmful substances in the compost [11]. But when the moisture content is less than $40 \%$, microbial activity will be reduced. The best effects of composting are found when the moisture content is between $50 \%$ and $70 \%$ [10]. In addition, the $\mathrm{pH}$ value will affect the growth environment of microbes, with a $\mathrm{pH}$ value of between 6 and 9 obtaining an optimal composting rate [12]. Nonetheless, few studies discuss the effect of composting parameters specifically on SMFCs. In this study we will focus on investigating the effects of composting factors on the performance of SMFCs to explore the most significant factors that would enable better power generation.

\section{Design and Methods of Experiments}

\subsection{Model of Experiments}

A batch-type of single-chamber solid microbial fuel cell (SMFC), shown in Figure 1, was adopted as the system structure for the experiment. The chamber material was made from an acrylic sheet, and carbon felt was selected as the electrode material. As carbon felt has a high porosity and large surface area, and is conducive to microbial growth [13], adhesion, and reduction of activation impedance [14], it was considered the best choice. The carbon felt was pretreated before the study by being soaked and heated at a condition of $90^{\circ} \mathrm{C}$ with a volume of $10 \%$ hydrogen peroxide solution for $3 \mathrm{~h}$, and then air-dried so as to increase the adhesion and proliferation of microbes [15]. The different chambers of the SMFCs were manufactured for particular experimental requirements. Figure 1a shows that the outer dimension of a SMFC chamber for measuring the different $\mathrm{C} / \mathrm{N}$ ratios and moisture content were set at $5 \mathrm{~cm} \times 5 \mathrm{~cm} \times 10 \mathrm{~cm}$. The working volume of the SMFC system was $200 \mathrm{~cm}^{3}$, and the electrode plate size was $4 \mathrm{~cm} \times 4 \mathrm{~cm} \times 0.5 \mathrm{~cm}$ (working area of $18 \mathrm{~cm}^{2}$ ). Figure $1 \mathrm{~b}$ shows the measurements for the $\mathrm{pH}$ experiments and as the $\mathrm{pH}$ sensors cannot be placed in the limited tank space displayed in Figure 1a, so the outer dimensions of the system chamber were changed to $15 \mathrm{~cm} \times 15 \mathrm{~cm} \times 10 \mathrm{~cm}$, with the working 
volume of the SMFC system changed to $2000 \mathrm{~cm}^{3}$, and the electrode plate size to $5 \mathrm{~cm} \times 10 \mathrm{~cm} \times 0.5 \mathrm{~cm}$ (working area of $65 \mathrm{~cm}^{2}$ ). The MFC system components were configured by placing the anode plate at the base of the system and burying the cathode plate at the interface of the solution and air. In the experiment, different substrates were added and analyzed for discussion pertaining to electricity generation.

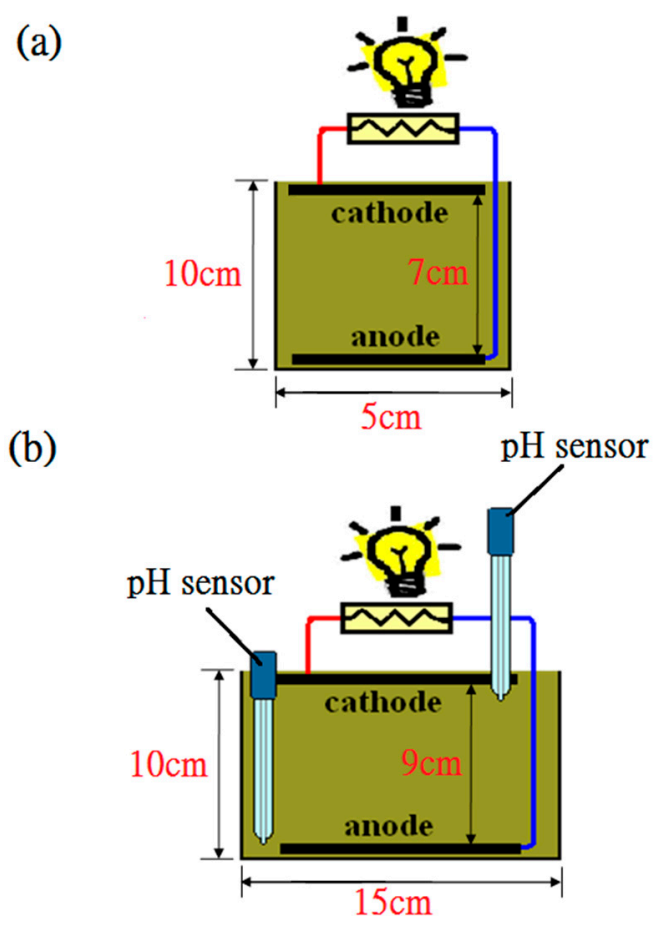

Figure 1. Schematic diagrams of solid microbial fuel cells (SMFC): (a) for carbon/nitrogen $(\mathrm{C} / \mathrm{N})$ ratio and moisture content; (b) for $\mathrm{pH}$ value.

\subsection{Composting Composition and Experiments}

This experiment explored the effects of composting conditions on SMFC electricity generation. The fixed substrate materials were regarded as important for composting as different substrates exhibit different composting performances. This experiment chose rice husks [16], soybean residue, coffee residue, and leaf mold as the raw materials for the SMFC substrates. The selection of substrates was mainly based on cellulose, which is considered to be the most abundant biopolymer as well as an ideal source of organic matter [17]. The selection of rice husks as a substrate was because rice is the staple food in Asia, and so the husks become agricultural waste in the production process. Adding rice husks to the compost in the SMFC chamber would enhance the hydraulic conductivity and the ventilation effect [18]. Additionally, soybean residue and coffee residue were chosen because soybean milk and coffee are arguably the favorite drinks of Asian nationals, thus creating a large volume of waste. Each substrate was mixed evenly at a ratio of $1: 1$, and factors influencing the compost such as $\mathrm{C} / \mathrm{N}$ ratio, moisture content, $\mathrm{pH}$ value and other operational conditions were adjusted. Then, finally $200 \mathrm{~cm}^{3}$ of substrate would be taken out and put in the SMFC chamber to enable the exploration of the impact of operational compost factors on the power performance of SMFCs.

In the experiments, the composting factors were adjusted as follows. Different substrates were combined and used to change the $\mathrm{C} / \mathrm{N}$ ratios [14]. Five groups of different $\mathrm{C} / \mathrm{N}$ ratios $(11.7: 1,27.8: 1$, 
$31.4: 1,31.7: 1,37.2: 1)$ were experimented with to explore the effect of the $\mathrm{C} / \mathrm{N}$ ratio on the power performance of SMFCs. In addition, different levels of moisture content (40\%, 60\%, 70\% and 80\%) were also trialed to investigate their impact on the power performance of SMFCs. The $\mathrm{pH}$ sensors were used to perceive the influence of $\mathrm{pH}$ value on the power performance of SMFCs during the composting process. Finally, a correlation analysis was applied to ascertain the effect of each composting factor on the SMFCs. This would prove very useful in improving the performance of SMFCs in the future.

\subsection{Measurements of SMFCs}

The setup of the measurement systems is shown in Figure 2. The experiments used data loggers and electrochemical analyzers to execute the electrical analysis of the SMFCs. A fixed resistor discharge ( $1 \mathrm{~K} \Omega$ ), polarization curve and $\mathrm{pH}$ were used for the analysis to assess the SMFC performance. The electrochemical analyzer (Jiehan 5600, Taichung, Taiwan) measures the polarization curves by using a dynamic potential scan and thereby obtains the limiting current and voltage of the SMFC.

On realizing the performance of the SMFC, a power, $\mathrm{P}$, defined by equation of $\mathrm{P}=\mathrm{IV}$ would be calculated by way of measuring the current intensity, I, and voltage, $\mathrm{V}$, simultaneously in this study.

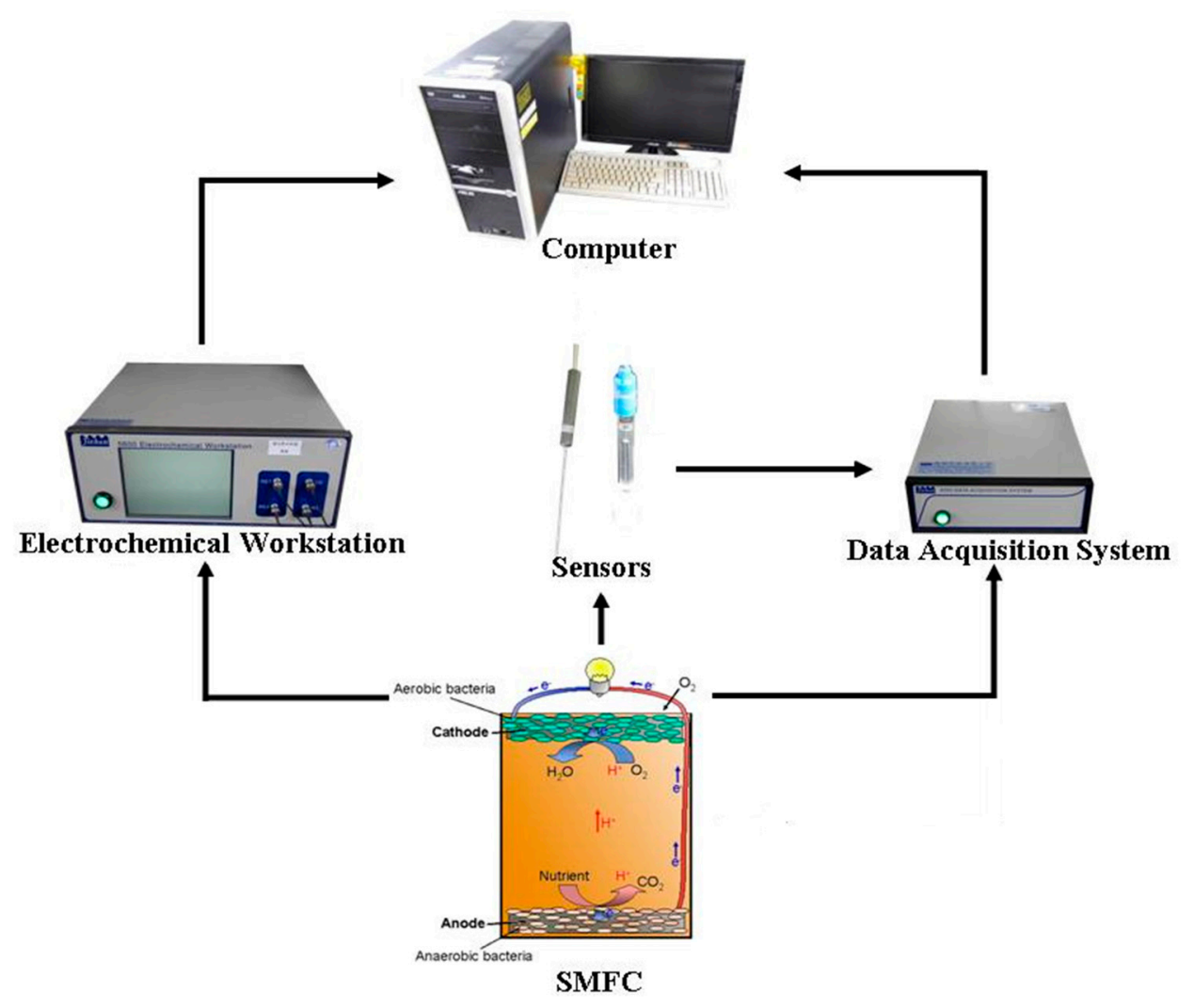

Figure 2. Diagram of the setup of the experimental measurement system.

The $\mathrm{C} / \mathrm{N}$ ratio and the moisture content are defined as follows: Equation (1) shows the number of nitrogen source substances that must be added to calculate the $\mathrm{C} / \mathrm{N}$ ratio:

$$
K=\frac{C_{1}+C_{2}}{N_{1}+N_{2}}
$$


In Equation (1), $\mathrm{K}$ is the $\mathrm{C} / \mathrm{N}$ ratio of mixed raw materials; $\mathrm{C}_{1}, \mathrm{C}_{2}, \mathrm{~N}_{1}$, and $\mathrm{N}_{2}$ are the organic carbon and nitrogen content [9] of the added organic raw materials, respectively. The $\mathrm{C} / \mathrm{N}$ ratios of each material used in this experiment are shown in Table 1.

Table 1. $\mathrm{C} / \mathrm{N}$ ratio of materials utilized.

\begin{tabular}{ccc}
\hline Substrate & C/N & References \\
\hline Soybean Residue & $3.4: 1$ & {$[19]$} \\
Leaf Mould & $60: 1$ & {$[20]$} \\
Coffee Residue & $20: 1$ & {$[21,22]$} \\
Rice Husk & $71: 1$ & {$[23]$} \\
\hline
\end{tabular}

The moisture content determination method is shown in Equation (2), using $105^{\circ} \mathrm{C}$ as the drying constant temperature, and a constant weight to measure the material weight loss:

$$
M=\frac{W_{m}-W_{c}}{W_{b}-W_{m}}
$$

where $\mathrm{M}$ is the weight ratio of waste, $\mathrm{W}_{\mathrm{m}}$ is the moisture content of the raw materials after mixing, $\mathrm{W}_{\mathrm{c}}$ is the moisture content of the original waste, and $\mathrm{W}_{\mathrm{b}}$ is the moisture content of the substrate after adjustment [15].

In the experiment of the impact of the $\mathrm{C} / \mathrm{N}$ ratio on the electricity generation of SMFCs, such common household organic compounds as soybean residue, coffee residue, leaf mould, and rice husks were selected, and different $\mathrm{C} / \mathrm{N}$ ratios were used to conduct the discharge study - the experimental model is shown in Figure 1a.The experiments were divided into five groups, and the substrate contents of each group are shown in Table 2 .

Table 2. Substrate table of each experiment.

\begin{tabular}{ccc}
\hline MFC & Substrates & C/N \\
\hline MFC-1 & Soybean Residue, Coffee Residue & $11.7: 1$ \\
MFC-2 & Soybean Residue, Coffee Residue, Leaf Mould & $27.8: 1$ \\
MFC-3 & Soybean Residue, Coffee Residue, Rice Husk & $31.4: 1$ \\
MFC-4 & Soybean Residue, Leaf Mould & $31.7: 1$ \\
MFC-5 & Soybean Residue, Rice Husk & $37.2: 1$ \\
\hline
\end{tabular}

\section{Results and Discussion}

To explore the impact of different composting factors on the power performance of SMFCs, the $\mathrm{C} / \mathrm{N}$ ratio, moisture content and $\mathrm{pH}$ value in the composting process, and their correlations with the electricity generation of MFCs, were examined to find the foremost correlation factor.

Figure 3 shows the experimental results of the polarization curves for different SMFCs. The results shown in Figure 3 indicate that the experimental group MFC-3 had the best electrical properties, and its $\mathrm{C} / \mathrm{N}$ ratio, displayed in Table 2 was 31.4:1. An optimal power density of $1.278 \mathrm{~mW} / \mathrm{m}^{2}$ was obtained at a $\mathrm{C} / \mathrm{N}$ ratio whose value was closest to the general compost's optimal $\mathrm{C} / \mathrm{N}$ ratio of $30: 1$. Therefore, the results show that the optimal composting conditions are the same as the optimal power performance of SMFCs. This finding seems to be reasonable and expected because the optimal $\mathrm{C} / \mathrm{N}$ ratio held in the 
composting process or biochemical process will both benefit the microbial activity. Conversely, when the $\mathrm{C} / \mathrm{N}$ ratio is too low (less than 20:1) as it was in MFC-1, microbial activity decreases because of insufficient nutrient sources. Similarly, when the C/N ratio in MFC-5 was too high (greater than 37:1), microorganisms would not complete decomposition because of excessive nutrient sources [9].

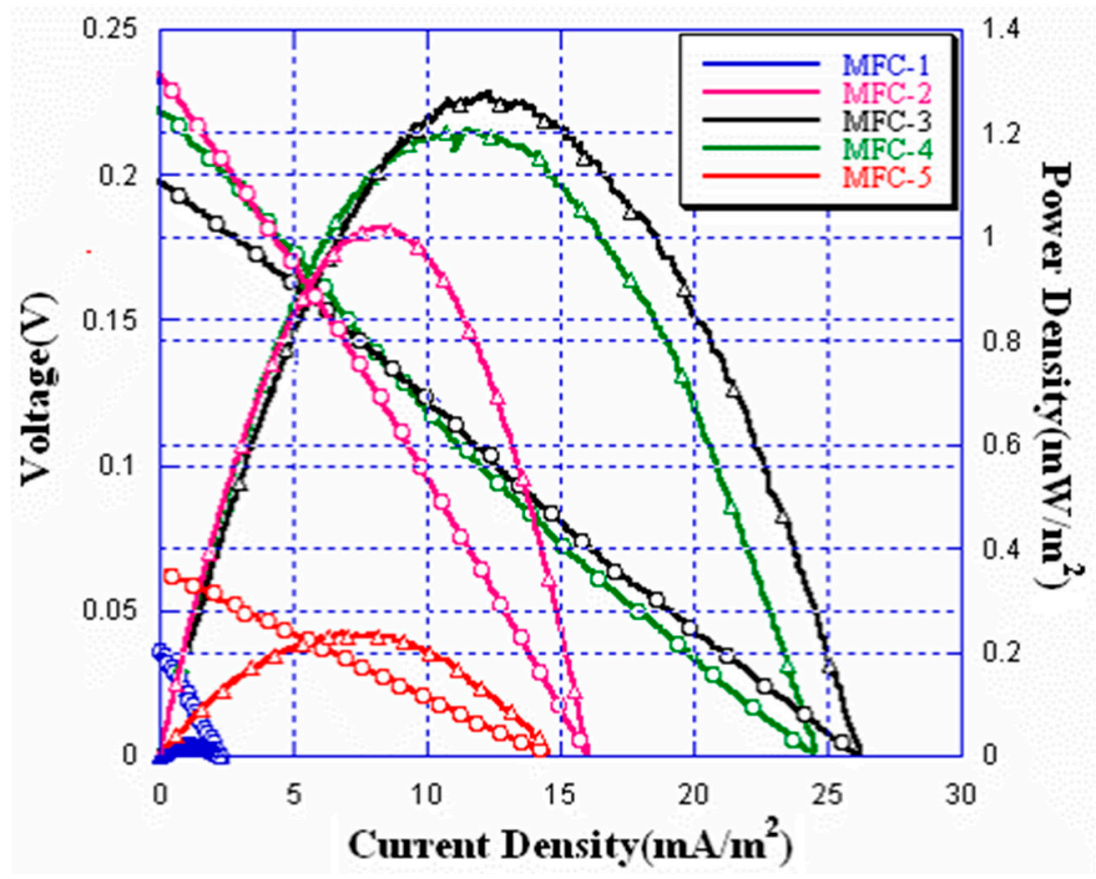

Figure 3. Effect of $\mathrm{C} / \mathrm{N}$ ratio on polarization curves of the experimental groups.

The impact of moisture content on the electrical performance of SMFCs was explored in our next study. Four different of moisture content $(40 \%, 60 \%, 70 \%$ and $80 \%)$ were tested at the optimal $\mathrm{C} / \mathrm{N}$ ratio (31.4:1) with a substrate made up by a combination of: soybean residue, coffee residue, and rice husks in a $1: 1$ ratio in the experiment.

The experimental model, as shown in Figure 1a, measured the voltammetric curve of each case to analyze the impact of moisture content on the power performance of SMFCs. Results shown in Figure 4 indicate that when the moisture content was $60 \%$, a better power density of $4.6 \mathrm{~mW} / \mathrm{m}^{2}$ was obtained. When the moisture content dropped to $40 \%$, there was almost no power generation. It might be inferred that a moisture content of $40 \%$ is too low, preventing the ions from being transferred [9]. Regarding the composting, when the moisture content was less than $40 \%$, fermentation was inhibited and microbial activity lowered [9], preventing the generation of power in the SMFC. When the moisture content was $80 \%$, a power density of $1.55 \mathrm{~W} / \mathrm{m}^{2}$ attained was much worse because of the growth of anaerobic bacteria, resulting from the appearance of water logged pores in the compost. This anaerobic condition would cause the aerobic bacteria to reduce and decrease the power generation of the SMFCs [24]. 


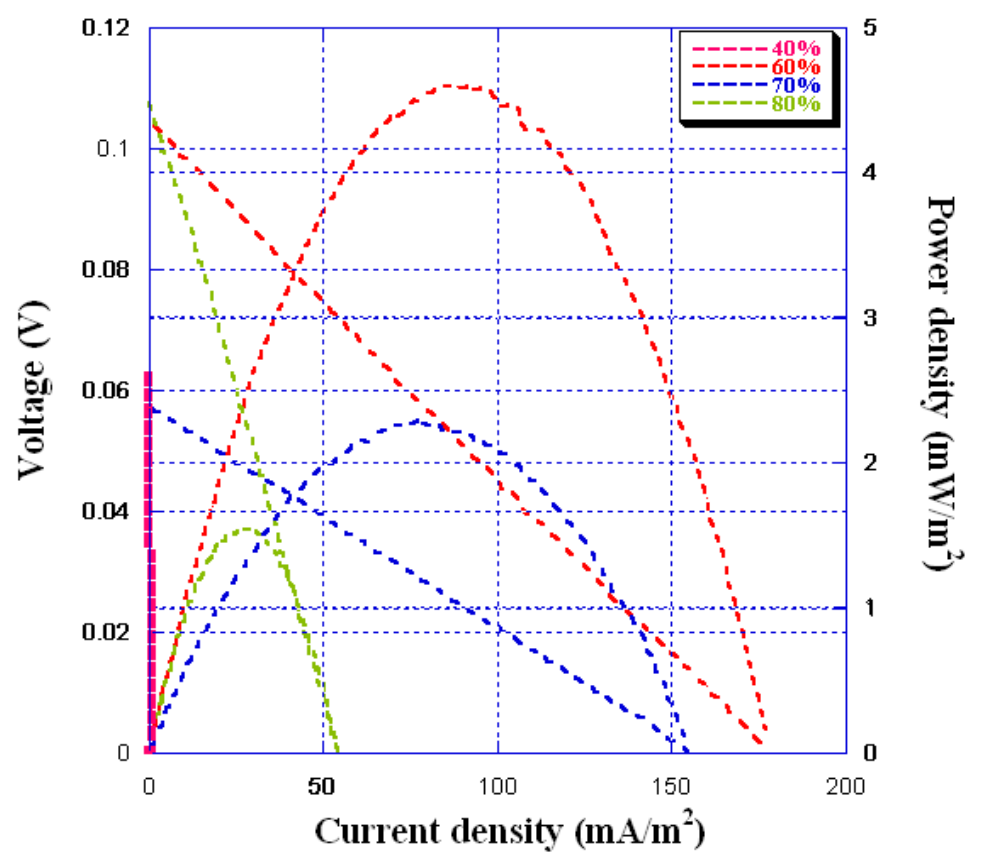

Figure 4. Comparison of voltammetric curves of cells under different moisture contents.

The variations of $\mathrm{pH}$ values near the anode/cathode plates during the discharge process were recorded in the experimental model shown in Figure 1b. Here, the substrate used the optimal $\mathrm{C} / \mathrm{N}$ ratio $(31.4: 1)$ combination (soybean residue, coffee residue, and rice husk mixed in a 1:1 ratio) and a moisture content of $60 \%$.

Results in Figure 5 show that the $\mathrm{pH}$ value measured near the anode was lower, but higher for the cathode region during the discharge process. In addition, over time a decreasing trend of $\mathrm{pH}$ near the anode region was found due to the $\mathrm{H}^{+}$proton being continuously produced because of the oxidation reaction during the degradation process of the SMFCs. On the other hand, when the anode $\mathrm{pH}$ value declined rapidly at the final discharge stage, the voltage also fell. This phenomenon would result from the accumulation of $\mathrm{H}^{+}$concentrations if the hydrogen ions could not pass through the membrane quickly enough. On this physical phenomenon, some similar explanations have been addressed [6,25,26]. Rozendal et al. [25] indicated that when hydrogen ions cannot pass to the cathode quickly enough, the anode $\mathrm{pH}$ will decrease while the cathode $\mathrm{pH}$ will rise. The anode $\mathrm{pH}$ drop will affect bacterial respiration, thereby affecting the current generation. Then the cathode $\mathrm{pH}$ increase will cause a blockage of passing ions. Mohan et al. [6] also found that when the anode $\mathrm{pH}$ value decreased to $\mathrm{pH}=5$, the electrical property would suddenly drop, but a decrease in the $\mathrm{pH}$ value would directly affect the power output, and an acidic $\mathrm{pH}$ value would inhibit the bacterial metabolism. The experiment by Cesar et al. [26] illustrated that when the $\mathrm{pH}$ difference between the cathode and anode was greater, the electrical properties would be worse. To summarize the above mentioned literature, the conclusions are similar to those found in this study where, the experiments were conducted to achieve a correlation analysis on the variations of output voltage and changes in cathode/anode $\mathrm{pH}$ value. A positive correlation between the output voltage and anode $\mathrm{pH}$ (correlation value 0.899), and a negative correlation between the output voltage and the cathode $\mathrm{pH}$ (correlation value -0.765 ) was found. Therefore, this evidence shows that the $\mathrm{pH}$ factor is very important to the power performance of SMFCs, with variations in anode $\mathrm{pH}$ having a highly positive effect on the voltage output of SMFCs. 


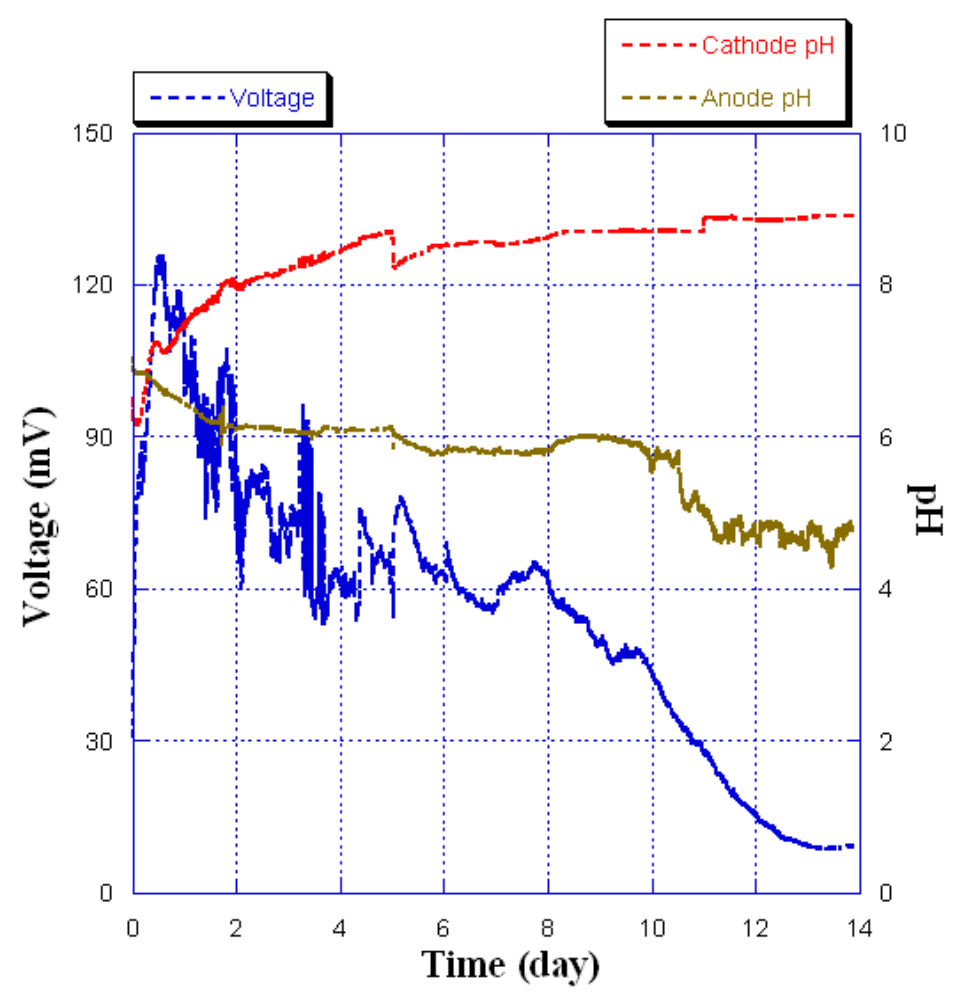

Figure 5. Variations of voltage output and $\mathrm{pH}$ value change with time at a discharge of $1 \mathrm{k} \Omega$ constant resistance.

\section{Conclusions}

This study discussed the impact of the composting conditions such as $\mathrm{C} / \mathrm{N}$ ratio, moisture content and $\mathrm{pH}$ value on the power performance of SMFCs. When the $\mathrm{C} / \mathrm{N}$ ratio was 31.4 and moisture content was $60 \%$, an optimal power density of $4.6 \mathrm{~mW} / \mathrm{m}^{2}$ was obtained. In the composting process, when the $\mathrm{pH}$ of the substrate was maintained between 6 and 8 (which was a condition suitable to composting) there was a better power performance. From the above conclusions, it was found that an optimal composting condition would promote a better power performance in SMFCs. These finding will provide positive information when applying compost to SMFCs.

\section{Acknowledgments}

The authors would like to acknowledge the kind funding support from MOST Taiwan under contract. \# MOST-104-2622-E-197-003-CC3 and MOST-103-2221-E-197-022-MY3.

\section{Author Contributions}

Author 1 Chin-Tsan Wang designs the research, experimental concept and writes the manuscript. Author 2 Yao-Cheng Lee revises the manuscript, interpretation of the results and reply of comments. Author 3 Fan-Ying Liao performs the experiment. All authors read and approved the final manuscript. 


\section{Conflicts of Interest}

The authors declare no conflict of interest.

\section{References}

1. Hinrichs, R.A.; Kleinbach, M. Energy Its Use and the Environment, 4th ed.; Brooks/Cole Publishing: Portland, OR, USA, 2005.

2. Arena, U. Process and technological aspects of municipal solid waste gasification: A review. Waste Manag. 2012, 32, 625-639.

3. Mata-Alvarez, J.; Macé, S.; Llabrés, P. Anaerobic digestion of organic solid wastes. An overview of research achievements and perspectives. Bioresour. Technol. 2000, 74, 3-16.

4. Sánchez-Monedero, M.A.; Roig, A.; Paredes, C.; Bernal, M.P. Nitrogen transformation during organic waste composting by the rutgers system and its effects on $\mathrm{pH}, \mathrm{EC}$ and maturity of the composting mixtures. Bioresour. Technol. 2001, 78, 301-308.

5. Lee, Y.; Nirmalakhandan, N. Electricity production in membrane-less microbial fuel cell fed with livestock organic solid waste. Bioresour. Technol. 2011, 102, 5831-5835.

6. Mohan, S.V.; Chandrasekhar, K. Solid phase microbial fuel cell (SMFC) for harnessing bioelectricity from composite food waste fermentation: Influence of electrode assembly and buffering capacity. Bioresour. Technol. 2011, 102, 7077-7085.

7. Pant, D.; van Bogaert, G.; Diels, L.; Vanbroekhoven, K. A review of the substrates used in microbial fuel cells (MFCs) for sustainable energy production. Bioresour. Technol. 2011, 102, 5831-5835.

8. Reimers, C.E.; Tender, L.M.; Fertig, S.; Wang, W. Harvesting Energy from the Marine Sediment-Water Interface. Environ. Sci. Technol. 2001, 35, 192-195.

9. Chen, X.X. Composting Technology and Equipment Manuals and Case Assembly; Industrial Development Bureau Ministry of Economic Affairs Publishing: Taipei, Taiwan, 2005.

10. Liang, C.; Das, K.C.; McClendon, R.W. The influence of temperature and moisture contents regimes on the aerobic microbial activity of a bio-solids composting blend. Bioresour. Technol. 2003, 86, 131-137.

11. Hamoda, M.F.; Qdais, H.A.A.; Newham, J. Evaluation of municipal solid waste composting kinetics. Resour. Conserv. Recycl. 1998, 23, 209-223.

12. Nakasaki, K.; Yaguchi, H.; Sasaki, Y.; Kubota, H. Effects of pH Control on Composting of Garbage. Waste Manag. Res. 1993, 11, 117-125.

13. Baranitharan, E.; Khan, M.R.; Prasad, D.M.R.; Teo, W.F.; Tan, G.Y.; Jose, R. Effect of biofilm formation on the performance of microbial fuel cell for the treatment of palm oil mill effluent. Bioprocess Biosyst. Eng. 2015, 38, 15-24.

14. Wang, C.T.; Liao, F.Y.; Liu, K.S. Electrical analysis of compost solid phase microbial fuel cell. Int. J. Hydrog. Energy 2013, 38, 11124-11130.

15. Feng, C.H.; Li, F.B.; Mai, H.J.; Li, X.Z. Bio-electro-Fenton process driven by microbial fuel cell for wastewater treatment. Environ. Sci. Technol. 2010, 44, 1875-1880. 
16. Zhou, Z.; Robards, K.; Helliwel, S.; Blanchard, C. Composition and functional properties of rice. Int. J. Food Sci. Technol. 2002, 37, 849-868.

17. Cheng, S.; Kiely, P.; Logan, B.E. Pre-acclimation of a wastewater inoculum to cellulose in an aqueous-cathode MEC improves power generation in air-cathode MFCs. Bioresour. Technol. 2011, 102, 367-371.

18. Zeytin, S.; Baran, A. Influences of composted hazelnut husk on some physical properties of soils. Bioresour. Technol. 2003, 88, 241-244.

19. Wong, J.W.C.; Mak, K.F.; Chan, N.W.; Lam, A.; Fang, M.; Zhou, L.X.; Wu, Q.T.; Liao, X.D. Co-composting of soybean residues and leaves in Hong Kong. Bioresour. Technol. 2001, 76, 99-106.

20. Cleveland, C.C.; Liptzin, D. C:N:P stoichiometry in soil: Is there a "Redfield ratio" for the microbial biomass? Biogeochemistry 2007, 85, 235-252.

21. Kondamudi, N.; Mohapatra, S.K.; Misra, M. Spent Coffee Grounds as a Versatile Source of Green Energy. J. Agric. Food Chem. 2008, 56, 11757-11760.

22. U.S. Environmental Protection Agency (EPA). URL. Available online: http://www.webcitation.org/ 6bAuh4GjH (accessed on 31 August 2015).

23. Rautaray, S.K.; Ghosh, B.C.; Mittra, B.N. Effect of fly ash, organic wastes and chemical fertilizers on yield, nutrient uptake, heavy metal content and residual fertility in a rice-mustard cropping sequence under acid lateritic soils. Bioresour. Technol. 2003, 90, 275-283.

24. Lovley, D.R. Microbial fuel cells: Novel microbial physiologies and engineering approaches. Curr. Opin. Biotechnol. 2006, 17, 327-332.

25. Rozendal, R.A.; Hamelers, H.V.M.; Buisman, C.J.N. Effects of Membrane Cation Transport on pH and Microbial Fuel Cell Performance. Environ. Sci. Technol. 2006, 40, 5206-5211.

26. Torres, C.I.; Lee, H.S.; Rittmann, B.E. Carbonate species as $\mathrm{OH}$-carriers for decreasing the $\mathrm{pH}$ gradient between cathode and anode in biological fuel cells. Environ. Sci. Technol. 2008, 42, 8773-8777.

(C) 2015 by the authors; licensee MDPI, Basel, Switzerland. This article is an open access article distributed under the terms and conditions of the Creative Commons Attribution license (http://creativecommons.org/licenses/by/4.0/). 